\title{
Urban growth trends in midsize Chilean cities: the case of Temuco
}

\author{
Tendências de desenvolvimento urbano em cidades médias do Chile: \\ o caso de Temuco
}

Carla Marchant Santiago ${ }^{[a]}$, Juan Pablo Frick Raggi[b], Luis Vergara Erices ${ }^{[]]}$

\footnotetext{
[a] Universidad Austral de Chile (UACh), Instituto de Ciencias Ambientales y Evolutivas, Valdivia, Chile

[b] Universidad Católica de Temuco (UCT), Escuela de Ciencias Ambientales, Temuco, Chile

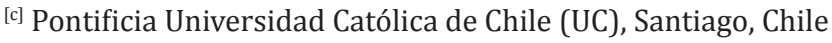

\begin{abstract}
Academic production about the main Chilean cities exceeds the existing documentation on intermediate cities, though they have shown interesting trends patterns in recent years which have changed the urban system in Chile. This paper aims to analyze the urban growth processes in Chilean intermediate cities using Temuco as a case study. It begins with an historical look at the city and then mentions that in the last decades this kind of cities have undergone new forms of segregation associated to real estate activities such as private communities, rural residential properties and new localization of services which have resulted in a fragmentation of urban space, a phenomenon reinforced by the consolidation of some satellite cities. At the same time, many urban problems associated to poverty, like a standstill of the regional economy and environmental pollution have appeared, jeopardizing the sustainability of these spaces, questioning current development parameters. The article ends considering the future challenges in Temuco's urban development.
\end{abstract}

Keywords: Urban development. Intermediate cities. Temuco.

\section{Resumo}

A produção acadêmica sobre as principais cidades do Chile é muito superior à documentação existente acerca de cidades intermediárias, embora, em anos recentes, encontram-se padrões de crescimento e tendências de grande interesse que levaram a mudanças no sistema urbano desse país. O objetivo deste artigo é analisar os processos de crescimento urbano nas cidades chilenas intermediárias, usando Temuco como estudo de caso. Começa-se com um olhar histórico sobre a cidade e, em seguida, discute-se como, nas últimas décadas, esses tipos de cidades têm passado por novas formas de segregação associadas com o setor imobiliário, tais como condomínios fechados, imóveis residenciais rurais e novos serviços de localização, o que tem provocado uma fragmentação do espaço urbano, um fenômeno reforçado pela consolidação de algumas cidades-satélites.

CMS is geographer; Dr. rer. nat. in Geography, e-mail: carla.marchant@gmail.com JPFR is geographer; Master in Territorial Planning, e-mail: juanpablofrick@gmail.com LVE is licentiate in Education; $\mathrm{PhD}^{\circ}$ in Architecture and Urban Studies, e-mail: l.vergara002@gmail.com 
Ao mesmo tempo, muitos problemas urbanos associados à pobreza, como o desligamento da economia regional e a poluição ambiental, vêm colocando em risco a sustentabilidade desses espaços e questionando os parâmetros atuais de desenvolvimento. Como conclusão, o artigo aponta os desafios futuros no desenvolvimento urbano em Teтuco.

Palavras-chave: Desenvolvimento urbano. Cidades médias. Temuco.

\section{Introduction}

Most of urban literature shows that research has been focused on big metropolitan areas. Transformations resulting from globalized neoliberal policies have been studied preferentially in big capitals in Latin America: Santiago, Buenos Aires, Sao Paulo, Mexico city, Lima and Bogota. All these spaces have experienced deep mutations as much in its morphology as in its internal configuration (Borsdorf \& Hidalgo, 2011; Coy \& Pohler, 2001; Cabrales \& Canosa, 2002; Parnreiter, 2002), up to the extreme that some authors denote to the coming of a new model of Latin-American city, characterized by fragmentation and privatization of urban space (Borsdorf, 2003; Janoschka, 2002).

Although the study of intermediate cities has gained importance in the last decades (Mertins, 2000; Stadel, 2001; Bolay \& Rabinovich, 2004; Haller \& Borsdorf, 2013, Henríquez, 2015 among others), the changes experimented by these are still being explored and the assumption is that these cities replicate the same effects observed in big cities at a different scale (Vergara, 2015).

The studies about socio-spatial segregation are examples of the previous statement. In Latin-America most of the research on segregation consequences considers big national capitals for the analysis (see Ruíz-Tagle \& López-Morales, 2014 for Santiago study case; Janoschka, 2006 for Buenos Aires study case; Ludeña, 2006 for Lima study case). Some studies in Chile point out other important cities study cases such as Valparaiso, Concepción (Sabatini et al., 2001) and other intermediate cities like Temuco (Toledo et al., 2000), show an outlook similar to Santiago: reduction of the segregation spatial scale, consolidation of private neighborhoods, peripheral social housing poorly served, social exclusion of the most vulnerable groups, etc.

Even though there are many common aspects between intermediate and big cities, some authors consider revising the effects of the variation in the urban scale of the socio-spatial phenomena because this can lead to think over the nature of urban development as it is understood up to these days (Capel, 2009). The previous concept is more relevant for the Chilean case considering population growth has slow down meanwhile in intermediate cities has strongly increased, mainly in the nineties decade (Rodríguez \& González, 2006).

Due to these facts, the aim of this research is to explore the urban development trends in Chilean intermediate cities during the last ten years, considering topics such as segregation, fragmentation and sustainability. The case study is Temuco, a city situated in the center of the southern zone in Chile, with many and accelerated transformations in the last decades. The methodological approach is a triangulation of primary and secondary sources: academic articles; data of national state institutions (i.e. census results on population and housing for different years: 1992-2002-2012) and international reports (data and information of OCDE publications); there's also primary sources data like building permits gathered by the authors in the fieldwork (data obtained of the Municipal Building Work Department) and pictures 'record, likewise satellite images of many years (1891-2013) to back up the urban growth process. The information was analyzed using the triangulation of the sources mentioned above.

The article is divided in five sections. Firstly, the changes taking place in the last decades in intermediate cities are analyzed focusing on the Chilean case and its development tendencies in depth. Secondly, the case study is presented together with a brief review of Temuco urban history. Thirdly, two of the most important trends that have characterized city growth in the last decades: segregation and fragmentation are reviewed. In the fourth place, an analysis of the economic, social and environmental problems that put at risk the urban sustainability of Temuco is made. In the fifth place, we present a review of Temuco case study, an open outline of the growing trends in intermediate Chilean cities in the last decades. 


\section{Intermediate cities: state of art in Chile}

Nowadays, $54 \%$ of the world population lives in cities and the estimate for 2050 is 66\% (ONU, 2014). This scenario differs from the one just some decades ago: in 1950 urban population was $29.1 \%$ of the whole population (Saladié \& Oliveras, 2010). The observed strong growth of urban population in the last decades not only sets up a strain on environment but it has also questioned the traditional definitions of a city. In Latin America this "conceptual crisis" has got at least two answers. On one hand, some authors have begun to talk about "living in a time of widespread urbanism", in which the boundaries are getting every time more diffuse, the same as the spatiality gotten by the relations of the city with the immediate surrounding and the rest of the planet (De Mattos, 2010). On the other hand, the physical transformations and of daily life in the cities have boosted the search of a definition out of the strict demographic and physical parameters which are usually used to define urban space, encouraging for term concepts closer to cultural and ontological traits (Hiernaux, 2006).

If it is difficult to define a city it is even more complex to state a typology according to its size. The facts and city scales differ in every country. An intermediate city for Spain can be a small one for China or Brazil. Population comparisons among cities in different countries make evident the conceptual strain about a "city" and they confuse even more the state of art. Even though the need to move forwards on a comprehensive and general definition of "city" in the new global context it is a not a task in our aims, it is necessary to clear up the dark state of the art in this concept, consequently and according to Chilean reality, we have chosen the definitions of urban spaces classification and typology of the Ministry of Housing and Urban Planning (Ministerio de Vivienda y Urbanismo, 2007). In the report of the Ministry the urban outline is set in four types of cities: small ones (5,000-19,999); minor-intermediate (20,000-99,999); largest intermediate $(100,000-300,000)$, and metropolitan area (+than 300,000 ).

According to the classification of the Ministry of Housing and Urban Planning, Chilean research focused on minor and largest intermediate cities are uncommon. Although a bigger interest for this kind of urban spaces is recognized, the prevailing dynamics seem unclear, it is necessary a general pattern which summarizes the Chilean trends, specially one accounting for the transformations originated by the neo liberal economy market. Notwithstanding, beyond the limitations due to the shortage of studies, some of them have made evident some trends that are taking place in urban growth in intermediate cities in Chile.

Intermediate cities are strongly associated to regional and surrounding dynamics (Concha et al., 2014). When the economic conditions in the region are good, these cities tend to channel and gather population growth and new productive investments, becoming jointed axis for regional development. An example is Puerto Montt city with a strong population and housing growth due to the aquaculture activity boom in the region (Rovira, 2000). In this way, the relation with the surrounding is complementary and not of invasive-domination lacking of control as it is in large metropolitan areas.

On the other hand, the insertion of real state capitals in intermediate cities seems to be smaller than in metropolitan areas. This is observed in the lack of gentrification processes in intermediate cities as compared with central or peri-central areas as the one observed in metropolitan areas (Contreras, 2011). Real estate investments in intermediate cities are made in vertically built condominiums and they are located on structuring roads and consolidated places in a city, where have traditionally lived the upper socioeconomic groups (Borsdorf, 2000).

There are some other reasons which have influenced intermediate cities growth. Burden, stress and insecurity of modern life in the city have motivated the search for quieter places to live, closer to nature but also near to urban life facilities. So, it is a new niche for real estate investment, especially when building closed condominiums and rural residential properties located in peripheral areas of intermediate cities (Azócar et al., 2008; Azócar et al., 2010). Even though this type of sub-urbanization process it is also patent in Chilean metropolitan areas (Borsdorf et al., 2007), in the case of intermediate cities these kind of projects have been located far from marginal and vulnerable sectors due to the bigger availability of land suitable for building and probably the lower prize per $\mathrm{m}^{2}$, therefore it is not possible set out for intermediate cities that real estate investments in peripheral areas mean a reduction in the spatial segregation scale as it is the case of large Latin American capitals through "gentrification with no expulsion" (Sabatini et al., 2009). 
Finally, as the penetration of real estate capital is lesser in intermediate cities, most of all in those in an economic vulnerable regional position, an important aspect of urban growth can be explicated with social housing building; the localization of them is peripheral because its construction is subordinated to market forces and the lower price of the land (Borsdorf, 2000; Vergara, 2015). Meanwhile in intermediate cities subjected to strong population growth resulting of good economic regional conditions, as a general fact social housing building has been expelled out of the city boundaries giving rise to the development of satellite dormitory towns concentrating vulnerable population living with poor facilities and badly equipped (Borsdorf et al., 2008).

Synthetizing, intermediate cities have followed some development patterns of big cities, however they seem to have some characteristics resulting not only of the relationship with their regional surrounding but also of the level of penetration of the economic capital in them.

\section{Temuco: history and evolution of an} intermediate city in a transformation process

Temuco is the regional capital of La Araucanía; it is in the south center intermediate depression at a height of $360 \mathrm{~m}$. above sea level and at $670 \mathrm{~km}$ from Santiago (Figure 1). It is flanked by Cautín river and two hills: Ñielol (330 m) and Conunhueno (350 m).

The city was founded in 1881 by Manuel Recabarren, Minister of Internal Affairs with only military goals (Pino, 1998; Aylwin, 2004). Until the middle of XIX century, this region, which is also called "La Frontera", was the natural border between Chilean state and mapuche

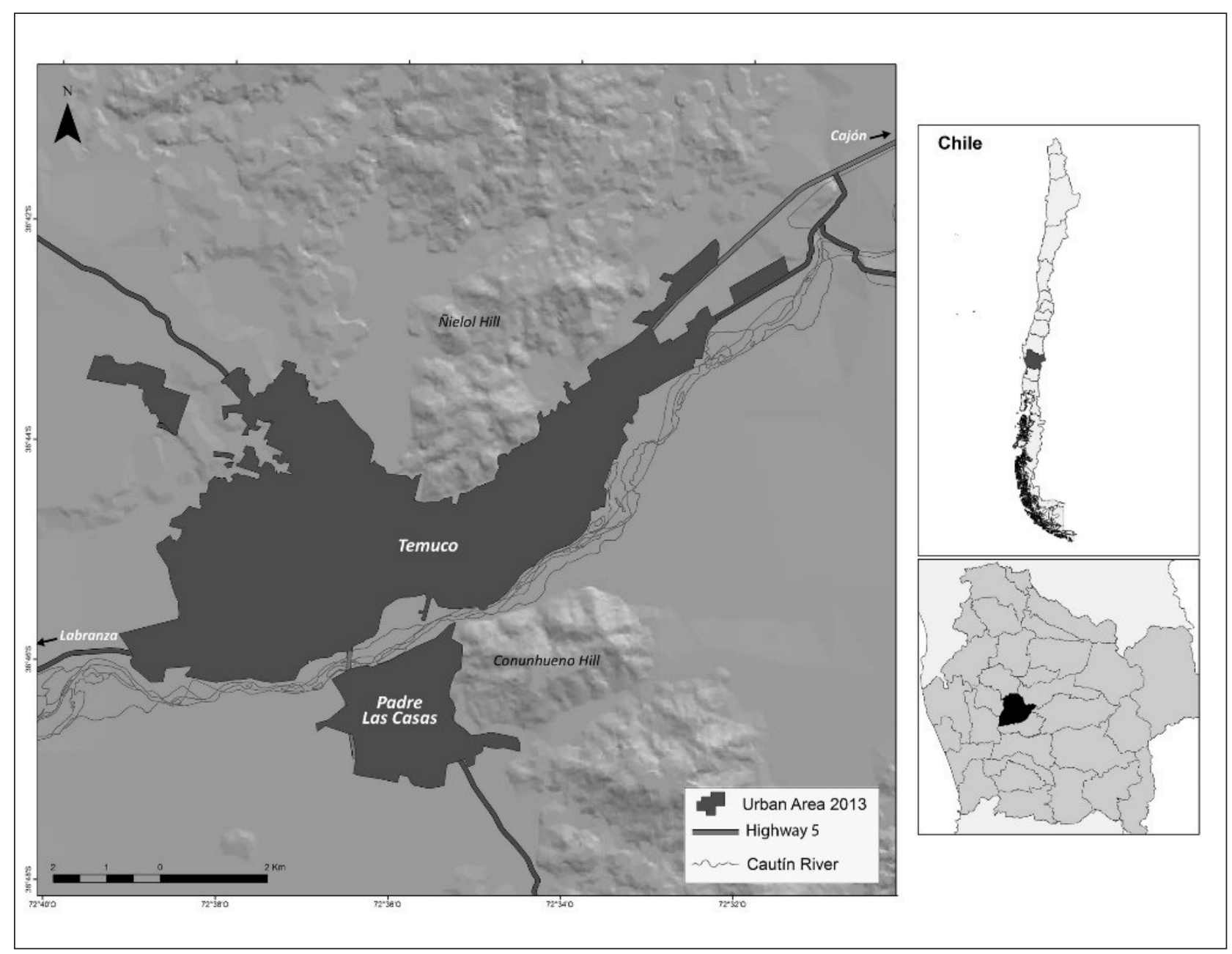

Figure $\mathbf{1}$ - Location of Temuco in La Araucanía Region

Source: Elaborated by the authors based on a Landsat Image (USGS, 2011). 
territory. Mapuche are indigenous people who had remained independent during Spanish conquest and the formation of Chilean nation. "La Frontera" situated between Malleco river in the north and Cautín river in the south, was a zone out of the sovereignty of the Chilean state. In line with the desire of articulating the center and south of Chile, so as to get continuity to the territory and national sovereignty (Núñez, 2009), around 1860 begins what the Chilean state called the military occupation of La Araucanía; a process accompanied by the foundation of forts or cities, symbolizing not only the State advancement over Mapuche territory but also a strategic positions for military management.

Afterward the first turbulent years, Temuco was considered as an important area as much as for the development of communications and for the exchange of assets and people between the central and southern region of the country. Accordingly, the state initiated the construction of new roads and railways enabling migration and trade between creole, pioneers and indigenous people (Municipalidad de Temuco, 2001). The new inhabitants of Temuco and surroundings devoted themselves to forestry, agriculture (mainly cereal) and cattle, these activities were the main income of the city allowing a consolidation of an emerging export model. Later on, they added their own business creating a small commercial zone near the railway station, where they sold products and regional handicraft.

The consolidation of the city and the initial economic boom provoked a fast population growth. Indeed, in 1881 Temuco had only 3,445 inhabitant (most of them soldiers) meanwhile in 1907 it was a prosperous urban center with 16,307 locals (Pino, 1998), concentrating the economic activity of the southern zone. National and international migrations and new state institutions settled in the zone as a result of the successful military operation initiated some years before. The quick growth was a reason to define the first urban boundary around 1892, a rule that may be considered the first tool for the city planning (Navarrete, 1957).

During the first three decades of XIX century, Temuco continued its expansion following the development model observed in some other Chilean cities (see Borsdorf \& Hidalgo, 2009): linear structures as a main axis (that is to say, avenues or tree-lined streets) and new neighborhoods close to the railway station. The strong rural-urban migration experienced by the city around the middle of XX century, a process derived from the industrialization model set up in Chile and to the internal economic crisis, were the origins of new problems in the city like traffic congestion, a bigger energetic demand, lack ok of basic housing services, and a polarized urban structure dividing wealthy class from lower ones (Garín et al., 2009; Vergara et al., 2015).

In those days, the lack of social housing and the economic hardship were the jumpstart for many locals to occupy illegally sub-urban lands; they made up neighborhoods, or better, slums (also called "población callampa" in Chile). There lived rural vulnerable population or mapuche descendants who had to face hard living conditions, like overcrowding, lack of the minimum standards of basic housing services (drinking water, sewage or electricity) and health problems (plagues and diseases). These slums were settled not only in Cautín riverside but also in other peripheral zones such as Pedro de Valdivia, Nuevo Amanecer, Santa Rosa, Santa Elena and San Antonio (Wörner, 2001). On the other hand, the consolidation of the center of the city and the urban expansion towards the west, especially along Alemania Avenue, concentrated the construction of middle and upper class neighborhoods (Figures 2 and 3). At the beginning of the 70's the surface of the city increased $400 \%$ (1962-1973) and this time is considered the most dynamic growing stage of Temuco (Wörner, 2001).

The uncontrolled growth of the slums ceased gradually since 1973, Pinochet's dictatorship started an eradication plan or, in some cases, a legalization of these settlements facilitating the control of the

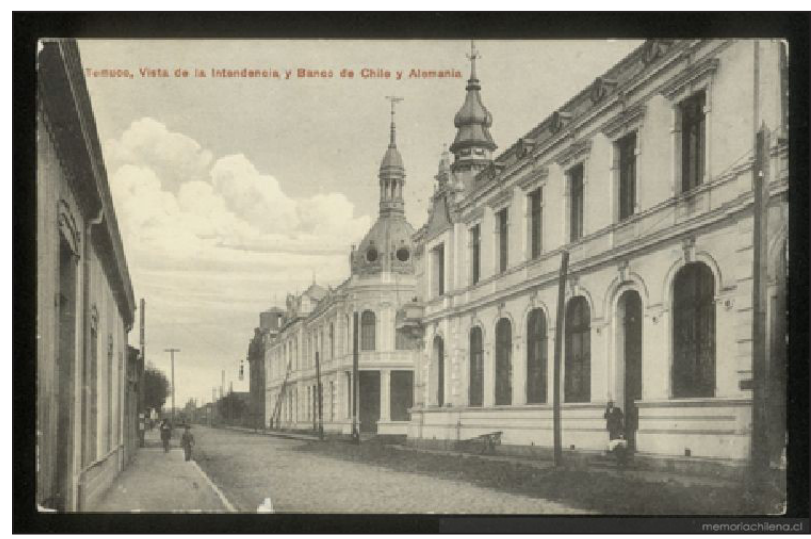

Figure 2 - The Alemania Avenue at the beginning of the XIX century Source: Memoria Chilena (1918). 


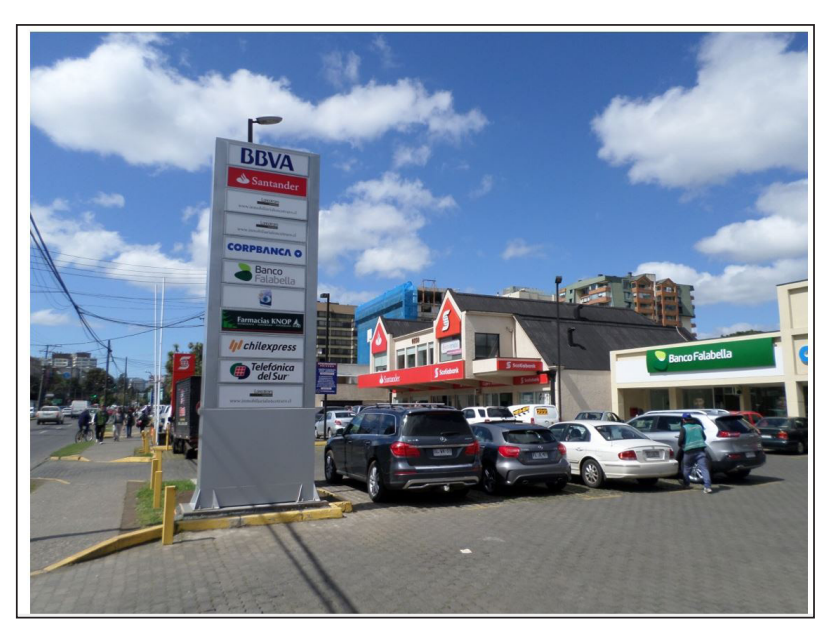

Figure 3 - Nowadays, the Alemania Avenue is an emerging commercial and services hub in the city

Source: Elaborated by the authors (2014).

"illegal" urban expansion. The neoliberal economic model and the urban development policies initiated in 1970 signified a liberalization of the land market and the removal of the law about "urban limits", defining the expansion of the city according to the needs of private real estate investors (Sabatini, 2000). The liberalization of the urban land market in 1979 brought about a significant growth and increased real estate companies. The "boom" diminished only during the economic crisis from 1981 to 1983 , but later in 1984 it was restarted with new urban projects highly profitable as much in the wealthy sectors of the city as, and like emerging projects, in municipalities related to low income population (Hidalgo, 2005; Sabatini, 2000). The reforms of urban policies have contributed to a transformation of the city. In the next subheading we are going to review two key trends to understand the development of the intermediate city in a neoliberal frame of segregation and segmentation.

Dynamics of neoliberal Temuco: segregation and fragmentation of an intermediate city

The installation of neoliberal policies in the city has produced and consolidated some dynamics that have strongly affected the configuration of the city, and also triggering new ones. These new urban reforms were for Temuco an impulse which helped to consolidate its urban development towards the west part of the city (Municipalidad de Temuco, 2001). At the late eighties and early nineties, Alemania Avenue started not only a densification process, but also urban functions changed, mostly from a residential use to a mixed use (residential - commercial). Nowadays, on Alemania Avenue there are several banks, restaurants, pharmacies, two shopping malls and even a Casino and a five stars hotel.

Since the beginning of the 90 s not only social housing were built in the city, as well new upper and middle class neighborhoods emerged in the peri-urban area occupying and changing the traditional land usage. In this process, since the 2000s real estate developers have an important role as active actors, who are leading a restructuration process in this "border" territory and contributing to model the urban growth. In the case of Temuco companies such as Fourcade, Socovesa and Aconcagua are responsible for the construction of almost all new residential projects in the peri-urban area. These projects are mostly gated communities and pleasure lots. Gated communities are characterized by oversized single detached houses and share wide areas for common sports and recreation facilities (Borsdorf \& Hidalgo, 2009). On the other hand, pleasure lots are single lots of no less than $5000 \mathrm{~m}^{2}$ which are governed by the Law 3516 of 1980 , created to avoid the atomization of lands lots for farming. These lots were since the middle of the 80s taken for individual housing (Borsdorf \& Hidalgo, 2011).

The speed of the recent city expansion can be interpreted looking at the building permits given by the municipality. Figure 4 shows the evolution of the approved surface of building permits for residential uses between 2002 and 2012. They have experienced an irregular pattern, which reached its peak in 2011, but had no continuity decreasing over $64.8 \%$ in 2012 (Observatorio Habitacional Minvu, 2013). At first glance this fluctuating rhythm could be explained by the growth experienced in the surrounding localities, which belongs to the conurbation such as Labranza, Cajon or Padre Las Casas. Other hypotheses trying to explain this situation pointed out the slowdown of the economy and the weak situation both of labor market and the bad performance of some regional indicators such as the generation of investment, which are among the lowest indexes compared to the national average of major cities in the country. Also the lack of a properly connectivity plan could be one factor explaining this scenario (PatagonLand, 2013). 
Examples of the most representative new urban projects built in Temuco are gated communities such as Praderas de Santa Carolina, Hacienda Las Mariposas, Praderas del Carmen (Figure 4). All this projects are conceived and promoted as an alternative for people who want to live in a rural environment but at the same time enjoying the proximity to the city and its facilities.

This kind of fragmented development is increasing and consolidating socioeconomic segregation and inequality, phenomena that could be observed in different degrees in most of the intermediate cities and metropolitan areas of Chile (Sabatini et al., 2001; Rodríguez, 2008; Azócar et al., 2008 for the case of Los Ángeles; Borsdorf et al., 2007 for Valparaíso; Azócar et al., 2003 for Chillán; Borsdorf et al., 2008 for Puerto Montt).

These segregations patterns observed in Chile do not differ from the rest in Latin America, this is associated to the phenomena of real estate operations performed by the companies in peripheral zones in the historic city center (Sabatini, 2000). The segregation consequences for poor people are assorted, from social disintegration caused by exclusion feelings to the formation of subcultures deviated from the current norms of a society (Sabatini et al., 2007; Kaztman, 2001, 2003).

The specific configuration of the type of segregation in an urban space, depends on of the particular traits of the society in which it is integrated, but as a general rule, socio-spatial segregation is aligned to socioeconomically factors. According to this, the phenomenon represents one of the most important dimensions helping to comprehend the occupation of every area in a city, considering the land value and also the accessibility to a given social sector to a space (Romero et al., 2006).

We can point out that as in metropolitan areas, in intermediate cities like Temuco gated communities and private neighborhoods have been built in the suburbs (Figure 5), however, these ones have been located far from the zones occupied by vulnerable people, a fact that has not contributed to produce spatial proximity between dissimilar socioeconomic groups. Consequently, the real estate market unlike Santiago, it has not worked to promote the spatial integration, but to consolidate economic differentiation in the urban space of intermediate cities.

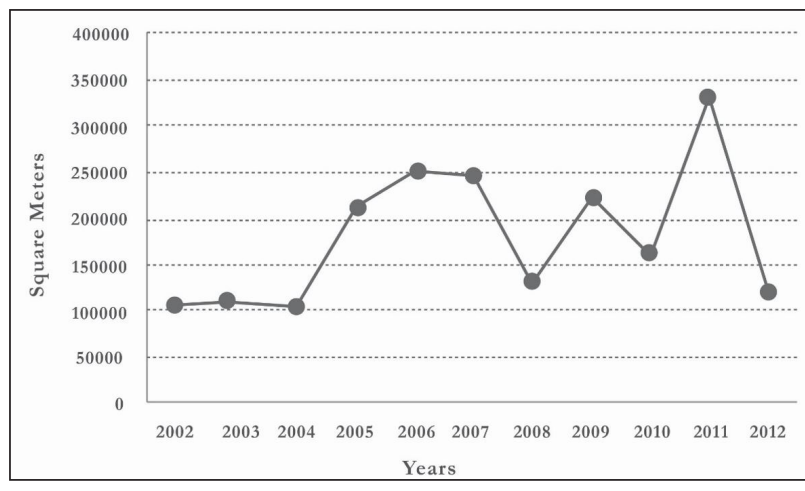

Figure 4 - Evolution of the approved surface of building permits for residential uses between 2002 and 2012

Source: Elaborated by the authors based on Observatorio Habitacional Minvu (2013).

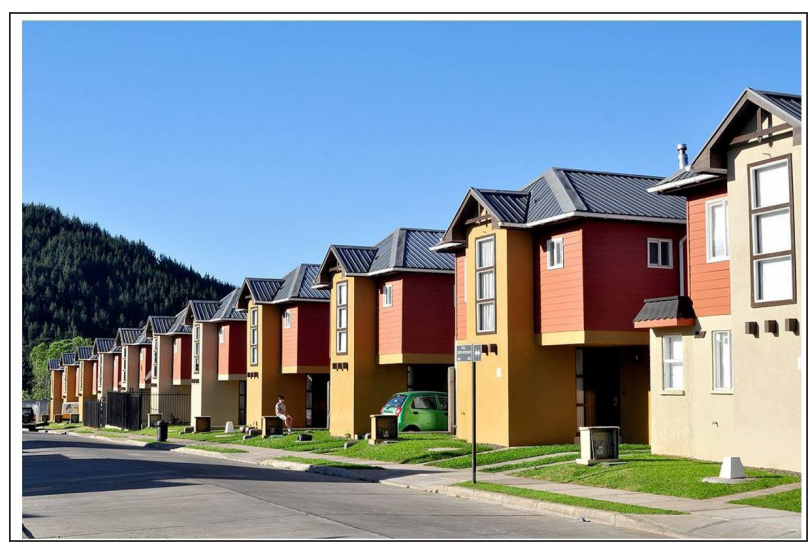

Figure 5 - Gated communities in the peri-urban area of Temuco Source: Elaborated by the authors (2014).

At the same time, satellites cities surrounding Temuco, like Cajón and Labranza, have been consolidated due to the building of the largest social housing complexes, this has contributed to fragment the urban space as well as to increase the socio spatial segregation of the city.

Summmarizing, since its foundation Temuco was considered as a political and institutional strategic point in order to give unity and spatial coherence to the Chilean State. Figure 6 shows the urban growth of Temuco since its origin until now. The city is characterized since its origins by its great economic, dynamic and demographic expansion, resulting from its great attractiveness and its status as regional capital, which influenced the arrival of investors and people mostly from its rural hinterland, looking for better living conditions. These factors played an important role to help consolidate this intermediate 


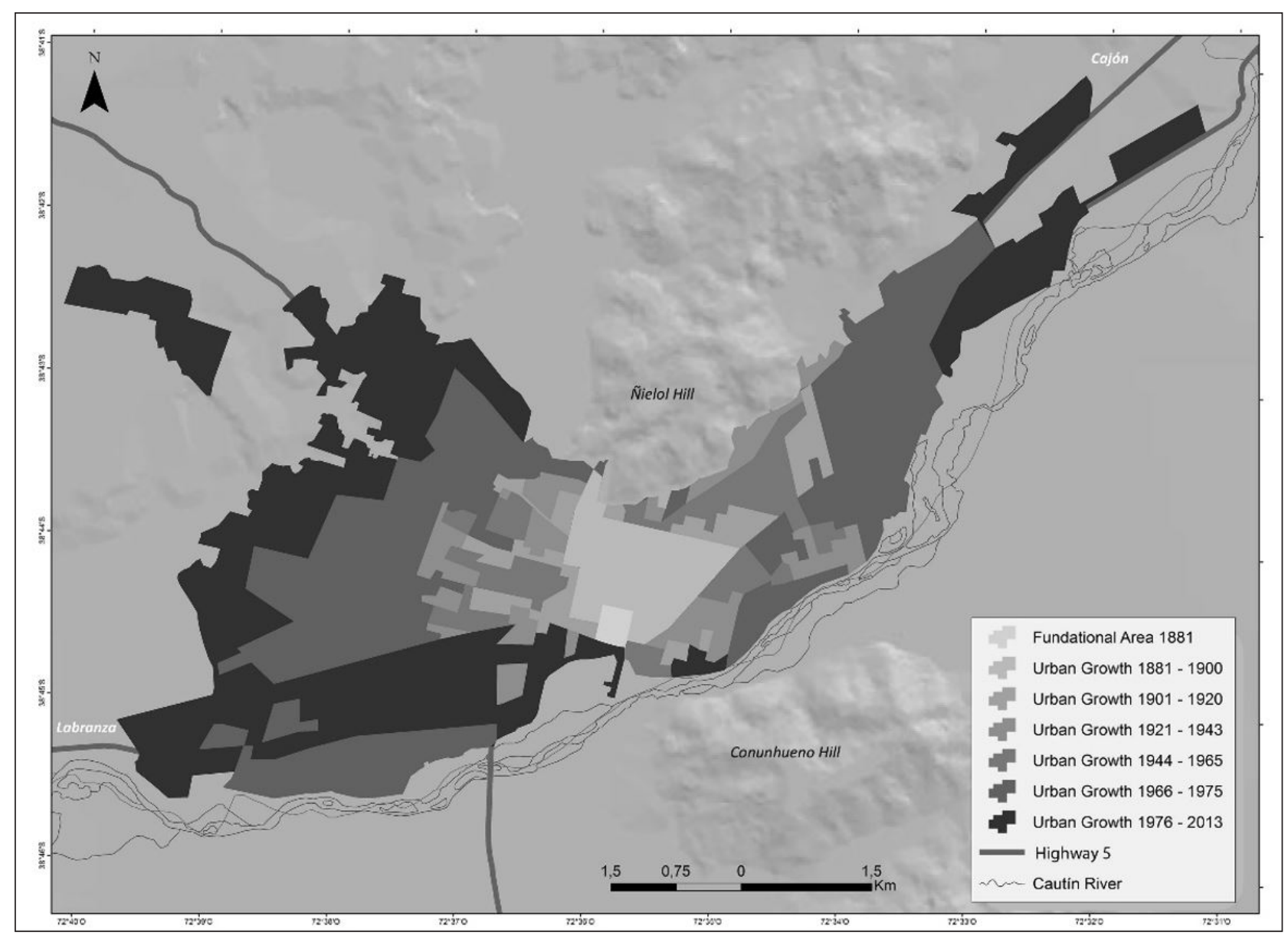

Figure $\mathbf{6}$ - Urban growth of Temuco since its origins until now

Source: Elaborated by the authors based on Municipalidad de Temuco (2007).

city in the Small South of Chile. However, the urban development process was not properly planned due to a number of deficiencies: predominance of reactive planning, uncompleted or non-updated instruments and non-efficient urban management, factors which influence the currently shape of the city.

\section{Factors affecting urban sustainability in Temuco}

In the previous section, we revised how the urban segregation and fragmentation dynamics triggered by neoliberal model have introduced in the cities a series of challenges for policymakers and authorities. During the last decades new problems for the cities have become evident: economic standstill, poverty and pollution, these have also meant a drop in migration attraction and as a consequence a loss in the potential growth of the city which is evident in the inter-census period 2002-2012. These are signs of the lack of urban sustainability of Temuco, according to our research.

Some of the underlying root causes that may explain the problems the city is facing are derived from the regional context. The Araucania Region shows in the past decade an important backwardness of its economic base. This situation could be explained by the limited direct foreign investments during the past ten years 2004-2014 (Figure 7). At the same period the average of this kind of investment reached $\$ 170$ million dollars in other regions of the country.

The regional figures have an impact in the growth patterns of the city. In other cases, not only regional capitals such as Valparaiso or Concepción have profited of new investments projects. In other intermediate cities such Antofagasta, the strong impact of mining foreign investments has contribute to fasten the urban growth process and to trigger a real estate boom in the past years, which on one hand means the revitalization 


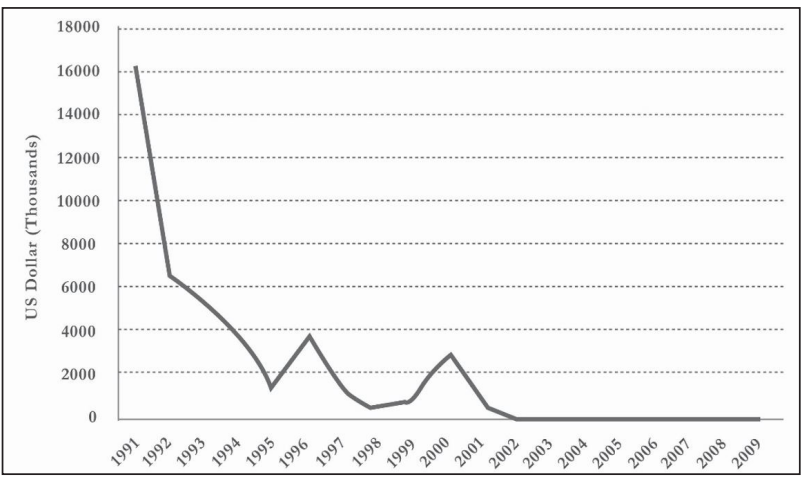

Figure 7 - Evolution of direct foreign investment in La Araucania Region (US Dollar)

Source: Ministerio Secretaría General de la Presidencia (2010).

of the local economy and the modernization of the city, but on the other hand also mean an explosive and not properly regulated urban planning (Cámara Chilena de la Construcción, 2013).

In the same line, indicators such as labor market participation and unemployment rate within the Region also shows a negative situation, resulting in a direct impact on city growth. In 2009 La Araucania reached $13.14 \%$ of unemployment population, and Temuco $11.93 \%$, both numbers are over the national level: 10.22\% (Ministerio Secretaría General de la Presidencia, 2010).

Conversely, in Chile poverty is defined taking as a reference the capability of a person to access to a basic food basket, which value is updated according to the evolution of prices (Casen, 2009). With this mechanism, it is possible to difference between poverty and extreme poverty $^{1}$. As already was mentioned, The Araucanía is the poorest region in the country with $18.08 \%$ of the total population living in this situation. In the case of Temuco, $15.36 \%$ of the population can be considerate as poor. This percentage is over the national average, which reaches $11.38 \%$. This condition has been noticed by the local authorities, who are developing many initiatives in order to expand and improve the employability and also to develop programs to reinforce economic and productive projects, most of them to strengthen the capacities of small entrepreneurships (Municipalidad de Temuco, 2007).

${ }^{1}$ According to Casen (2009), the extreme poverty line is defined in US\$60 (\$32,067 Chilean pesos) and the poverty line in US\$120 (\$64,134 Chilean pesos). These amounts were calculated based on the currency from January 17th, 2014.
Both the negative and fragile economic conditions and the poverty situation that in general this region shows are key factors threatening the economic development and the possibilities of Temuco to consolidate itself as a crucial urban center in South Chile.

The rapid urban growth experienced in Temuco between 1990 and 2000 has also meant an exacerbation of some environmental problems. One of these critical situations is the rise of air pollution. There are several reasons for this situation. Sanhueza et al. (2006) mentions as one of the most important factor, the use of wood cook stoves or wood stoves as heating system. Added to this, the situation becomes more critical with the use of wet wood in winter season, which is cheaper and easy to find. In fact, Sanhueza et al. (2008) estimated that $87 \%$ of PM10 winter emissions originate from residential wood combustion. A second cause could be related to the progressive increase of the motorization rate, which is high correlated to the household income and the density of the city (UDP, 2012). For Temuco this indicator shows an increase of 39\% in the period 1998-2007 (105 per 1,000 inhabitants in 1998 to 146 cars per 1,000 inhabitants in 2007) (SECTRA, 2007). Both factors are responsible for several episodes of environmental emergency along the year. In 2013 Temuco was declared as saturated zone by fine particulate matter (PPM 2.5) and a new plan of decontamination is expected.

Another important aspect to improve quality of life of the population which is in direct relation with sustainable development is related to infrastructure and the access to urban green areas. Public spaces and green areas provide social and ecological functions within urban environments (Maas et al., 2009). In this sense, the lack of adequate public spaces and green areas in the city are evidenced also a critical situation. Although according to official statistics, Temuco has a surface of green areas and public spaces with municipal maintenance of $4 \mathrm{~m}^{2} /$ inhabitant, which is over the average of functional urban areas $\left(3.49 \mathrm{~m}^{2}\right)$, this number is under the World Health Organization parameter, who recommends $9 \mathrm{~m}^{2}$ /inhabitant (WHO, 2010). This situation can be explained by the disparities between municipalities in term of per capita municipal own-source revenue, where the difference between rich and poor municipalities along the country is extreme (Reyes \& Figueroa 2010) and impact the capabilities of the local government to manage their priorities of investment. 
We believe that as much as the regional economic regional standstill as the high poverty level and environmental pollution, all of them shown in Temuco most of all in the last millennium, are factors with a direct influence in the loss of migratory attraction to the city at a national level. The most direct consequence of this phenomenon is the deceleration of population growth that the city had had during the nineties (Figure 8), nevertheless, we believe that if the conditions continue to be the same there is a trend marked by the socio-environmental lack of sustainability.

\section{Final remark and suggestions}

Although Chile is a highly urbanized country with almost $77 \%$ of its population living both in metropolitan areas or other functional urban areas such as medium sized urban areas or intermediate cites, the speed of change and the quality of this growth is quite heterogeneous between cities. Inter and intra urban disparities, socio-spatial segregation, inequality and inadequate access to public services are now phenomena not restricted to big cities.

According to the background information exposed in this research, Figure 9 shows a model which helps to make a generalization of Temuco's growth process. This kind of generalization based on Borsdorf (2003) Latin American urban development model is a preliminary and useful attempt to demonstrate that the dynamics of urban structuring in intermediate cities are comparable to major cities and the globalization effects are also impacting their urban development. Gated communities, pleasure lots in the fringe, and also an early but strong fragmentation represented by the spatial separation of different social groups in

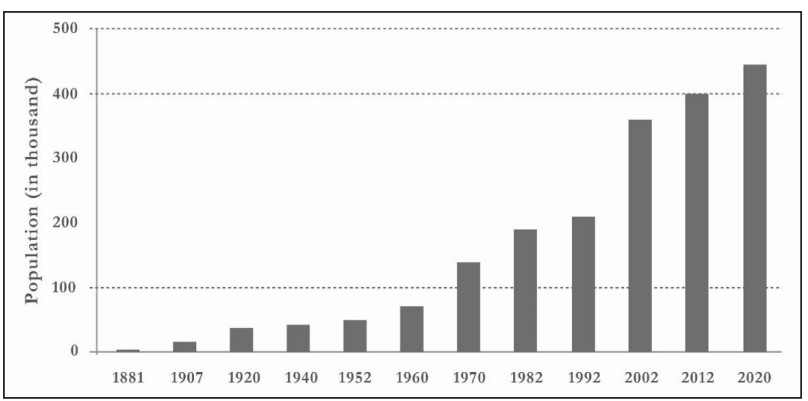

Figure 8 - Population according to Census data (INE), OECD information for 2012 and 2020's projection (INE)

Source: Based on data from INE $(1992,2002,2010)$ and OECD (2013). the city according to income differences are visible phenomena.

However, in the case of Temuco there are some differences. First, the growth pattern associated to middle-to upper and upper classes neighborhoods is oriented to the west ${ }^{2}$, meanwhile lower classes are located in peripheral areas in the surroundings of the Cautin River and the Ñielol hill. The expansion of new urban structures, such as the Parcelas de agrado (leisure plots) by high income groups in peri-urban areas is also a remarkable aspect of this process. Secondly, although most of the commercial activities and services are concentrate mostly in the central business district (CBD), in the past ten years they have experienced an expansion towards the Alemania avenue, also in the west part of the city. Thirdly, the speed of these changes is still slower than in metropolitan areas. Artefacts of globalization (De Mattos, 2003) such as enterprise and industrial innovation in the periphery (logistic centres, business centres) or big shopping malls or commercial centres are still not visible.

This new drawing of the city left plenty of open questions and challenges that Temuco as intermediate city should be face in order to achieve a gravitating role in Chilean urban system and also a more sustainable future.

One of the most relevant challenges is related to strengthen its economic function. Urban areas are the motor of the Chilean economy (OECD, 2013). In the Araucania Region, currently socioeconomic dynamics and the unresolved historical conflicts are responsible for the emerging of a loss of attractiveness for business and for these to attract migrant workers. These situations are influencing the currently economic situation of Temuco and its role in Chilean urban system. This scenario could be different if the dynamism that most of the medium and small cities showed in the past decade were seriously taking into account by policy makers and urban policies were capable to consider that physical capital, infrastructure and innovation are growth determinants that can enhance economic performances in these cities; and therefore not focuses almost all the investments plans exclusively in Santiago and the other metropolitan areas. The higher and not stopped inequality and

${ }^{2}$ For the case of Santiago, this pattern follows the opposite way. High income municipalities are located in the east part of the city. More information in Borsdorf (2003). 


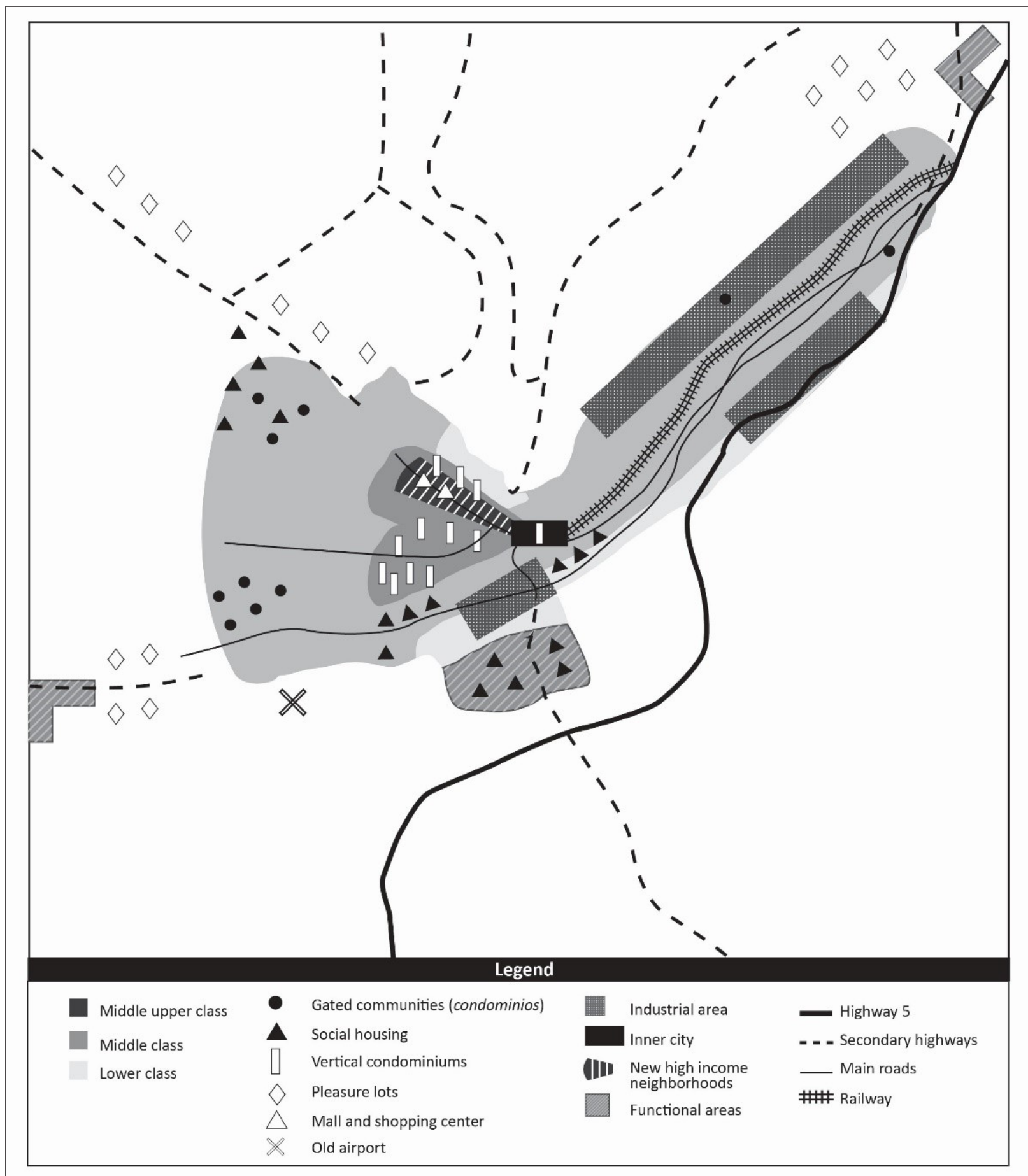

Figure 9 - Proposal of the Latin American urban development model (Borsdorf, 2003) applied to Temuco city Source: Elaborated by the authors (2014).

poverty rate evidenced in Temuco are consequences of the centralized Chilean urban policy. Consider these ideas in currently discussions of how to improve sectorial and urban development policies could be one measure in order to improve competitiveness of intermediate cities.
Finally, it should be taken into account that this type of city is still in a growing stage and passing through deeper transformations than big cities do, that's why is extremely significant in a medium term to act in two ways. Firstly, think over the urban transformations experienced by intermediate cities, 
trying to understand how they affect people's quality of life, especially of those belonging to vulnerable groups. Secondly, knowledge about urban changes in intermediate cities should be the foundation on which new strategies for urban planning are implemented, seeking an answer, ideally with a decentralized approach to the local needs and the strains that put at risk sustainability in each of them.

\section{References}

Aylwin, J. (2004). La política pública y el derecho de los mapuches a la tierra y al territorio. In J. Aylwin (Ed.), Derechos humanos y pueblo indígenas: tendencias internacionales y contexto chileno (p. 279-291). Temuco: Universidad de La Frontera.

Azócar, G., Aguayo, M., Henríquez, C., Vega, C., \& Sanhueza, R. (2010). Patrones de crecimiento urbano en la Patagonia chilena: el caso de la ciudad de Coyhaique. Revista de Geografía Norte Grande, (46), 85-104.

Azócar, G., Henríquez, C., \& Sanhueza, R. (2003). Cambio en los patrones de crecimiento en una ciudad intermedia: el caso de Chillán en Chile Central. EURE. Revista Latinoamericana de Estudios Urbano Regionales, 29(87), 79-92. http://dx.doi. org/10.4067/S0250-71612003008700006.

Azócar, G., Henríquez, C., Valenzuela, C., \& Romero, H. (2008). Tendencias sociodemográficas y segregación socioespacial en Los Ángeles, Chile. Revista de Geografía Norte Grande, (41), 103-128.

Bolay, J., \& Rabinovich, A. (2004). Intermediate cities in Latin America risk and opportunities of coherent urban development. Cities (London, England), 21(5), 407-421. http://dx.doi.org/10.1016/j.cities.2004.07.007.

Borsdorf, A. (2000). El desarrollo urbano de Valdivia: estudio de caso en una ciudad mediana. Espacioy Desarrollo, $12,45-81$.

Borsdorf, A. (2003). Cómo modelar el desarrollo y la dinámica de la ciudad latinoamericana. EURE - Revista Latinoamericana de Estudios Urbano Regionales, 29(86), 37 49.http://dx.doi.org/10.4067/S0250-71612003008600002.

Borsdorf, A., \& Hidalgo, R. (2009). The fragmented city: changing patterns in Latin American Cities. The Urban Reinventors Online Journal, 2(9), 1-18.
Borsdorf, A., \& Hidalgo, R. (2011). Fragmentierende Stadtentwicklung unter Bedingungen der Globalisierung: Ergebnisse aus Santiago de Chile. Geographica Helvetica, 66(2), 122-131. http://dx.doi.org/10.5194/gh-66-122-2011.

Borsdorf, A., Hidalgo, R., \& Sánchez, R. (2007). A new model of urban development in Latin America: the gated communities and fenced cities in the metropolitan areas of Santiago de Chile and Valparaíso. Cities (London, England), 24(5), 365-378. http://dx.doi.org/10.1016/j. cities.2007.04.002.

Borsdorf, A., Sánchez, R., \& Marchant, C. (2008) Aprendiendo de los errores: La necesidad de cambios a la política nacional de vivienda en ciudades intermedias chilenas. In X Coloquio Internacional de Geocrítica. Barcelona: Scripta nova. Retrieved in 13 May 2015, from http://www.ub.es/ geocrit/-xcol/166.htm

Cabrales, L., \& Canosa, E. (2002). Nuevas formas y viejos valores: urbanizaciones cerradas de lujo en Guadalajara. In L. Cabrales (Ed.), Ciudades cerradas: países abiertos (p. 93-116). Guadalajara: Universidad de Guadalajara.

Cámara Chilena de la Construcción. (2013). Desarrollo inmobiliario: el nuevo rostro de Antofagasta (Report No. 2). Antofagasta: Diario de la Cámara Chilena de la Construcción.

Capel, H. (2009). Las pequeñas ciudades en la urbanización generalizada y ante la crisis global. Investigaciones geográficas, 70, 7-32.

Casen. (2009). Encuesta de caracterización social. Santiago: Ministerio de Desarrollo Social.

Concha, C., Errazuriz, T., Letelier, F., Michelitti, S., Rasse, A., \& Salcedo, R. (2014). ¿Urbano o Rural? Repensando territorios, discursos y prácticas al margen de la metrópolis. In Congreso urbano no-metropolitano (p. 1-11). Talca.

Contreras, Y. (2011). La recuperación urbana y residencial del centro de Santiago: nuevos habitantes, cambios socioespaciales significativos. EURE - Revista Latinoamericana de Estudios Urbano Regionales, 37(112), 89-113. http:// dx.doi.org/10.4067/S0250-71612011000300005.

Coy, M., \& Pohler, M. (2001). Wohnghettos der Privilegierten. Die Fragmentierung der brasilianischen Stadt. Fallbeispiele aus Rio de Janeiro und São Paulo. Matices: Zeitschrift zu Lateinamerika. Spanien und Portugal, 8(29), 8-12.

De Mattos, C. (2003). Globalización y transformación metropolitana en el caso de Santiago. In F. Arenas, R. Hidalgo, \& J. Coll (Eds.), Los nuevos modos de gestión de la 
metropolización (p. 27-55). Santiago de Chile: Universidad Católica de Chile.

De Mattos, C. A. (2010). Globalización y metamorfosis metropolitana en América Latina: de la ciudad a lo urbano generalizado. Revista de Geografía Norte Grande, 47, 81-104.

Garín, A., Salvo, S. \& Bravo, G. (2009). Segregación residencial y políticas de vivienda en Temuco: 1992-2002. Revista de Geografía Norte Grande, 44, 113-128.

Haller, A., \& Borsdorf, A. (2013). Huancayo metropolitano. Cities (London, England), 31, 553-562. http://dx.doi. org/10.1016/j.cities.2012.04.004.

Henríquez, C. (2015). Modelación de patrones de crecimiento en ciudades medias chilenas: ¿se fortalece el desarrollo urbano sustentable? In C. Bellet, E. Melazzo, M. E. Beltrão Sposito, \& J. M. Llop (Eds.), Processos de urbanização recente em cidades medias/intermédias: entre escalas geográficas e diferentes dinâmicas territoriais. Lleida: Universidad de Lleida.

Hidalgo, R. (2005). Transformaciones socioterritoriales asociadas a proyectos residenciales de condominios en comunas de la periferia del área metropolitana de Santiago. Revista INVI, 20(54), 104-133.

Hiernaux, D. (2006). Repensar la ciudad: la dimensión ontológica de lo urbano. Liminar. Estudios sociales y humanísticos, 4(2), 7-17.

Instituto Nacional de Estadísticas - INE. (1992). XVI censo de población y $V$ de vivienda. Santiago: INE.

Instituto Nacional de Estadísticas - INE. (2002). XVII censo de población y VI de vivienda. Santiago: INE.

Instituto Nacional de Estadísticas - INE. (2010). Proyecciones de población. Santiago: INE.

Janoschka, M. (2002). El nuevo modelo de la ciudad latinoamericana: fragmentación y privatización. EURE - Revista Latinoamericana de Estudios Urbano Regionales, 28(85), 1120. http://dx.doi.org/10.4067/S0250-71612002008500002.

Janoschka, M. (2006). El modelo de ciudad latinoamericana. Privatización y fragmentación del espacio urbano de Buenos Aires: el caso Nordelta. In M. W. Guerra. Buenos Aires a la deriva: transformaciones urbanas recientes ( $\mathrm{p}$. 96-131). Buenos Aires: Editorial Biblos.

Kaztman, R. (2001). Seducidos y abandonados: el aislamiento social de los pobres urbanos. Revista CEPAL, 75, 171-189.
Kaztman, R. (2003). La dimensión espacial en las políticas de superación de la pobreza urbana. Revista CEPAL, 59, 1-48.

Ludeña, W. (2006). Ciudad y patrones de asentamiento: estructura urbana y tipologización para el caso de Lima. EURE - Revista Latinoamericana de Estudios Urbano Regionales, 32(95), 37-59. http://dx.doi.org/10.4067/ S0250-71612006000100003.

Maas, J., van Dillen, S. M. E., Verheij, R. A., \& Groenewegen, P. P. (2009). Social contacts as a mechanism behind the relation between green space and health. Health \& Place, 15(2), 586-595. http://dx.doi.org/10.1016/j. healthplace.2008.09.006. PMid:19022699.

Memoria Chilena. (1918). Banco de Chile. Temuco. Retrieved in 10 May 2014, from http://www.memoriachilena.cl/602/ w3-article-77223.html

Mertins, G. (2000). Ciudades medianas en América Latina: criterios indicadores y el intento de un modelo de su diferenciación socio-espacial y funcional. Espacio y Desarrollo 12, 11-24.

Ministerio de Vivienda y Urbanismo. (2007). Medición de la superficie ocupada por las ciudades de Chile de más de 15.000 Habitantes: 1993-2003. Santiago de Chile: Ministerio de Vivienda y Urbanismo.

Ministerio Secretaría General de la Presidencia. (2010). Plan Araucanía: invirtiendo en personas y oportunidades. Santiago: Ministerio Secretaría General de la Presidencia. Municipalidad de Temuco. (2001). Plan regulador comunal de Temuco: memoria explicativa. Temuco: Municipalidad de Temuco.

Municipalidad de Temuco. (2007). Plan de desarrollo comunal. Temuco: Municipalidad de Temuco.

Navarrete, G. (1957). Evolución de la ciudad de Temuco (Thesis title Architect). Facultad de Arquitectura, Universidad de Chile, Santiago de Chile.

Núñez, A. (2009). La formación y consolidación de la representación moderna del territorio de Chile: 1700-1900 (Thesis for PhD in History). Pontificia Universidad Católica de Chile, Santiago de Chile.

Observatorio Habitacional Minvu. (2013). Tendencias permisos de edificación. Santiago: Ministerio de Vivienda y Urbanismo Alameda. Retrieved in 13 May 2015, from http://www. observatoriohabitacional.cl/opensite_20080122171157.aspx 
Organisation for Economic and Co-Operation - OECD. (2013). National urban policy reviews: the case of Chile. Paris: OECD.

Organização das Nações Unidas - ONU. (2014). World urbanization prospects: the 2014 revision. New York: ONU.

Parnreiter, C. (2002). La Ciudad de México: el camino hacia una ciudad global. EURE. Revista Latinoamericana de Estudios Urbano Regionales, 28(85), 89-120. http:// dx.doi.org/10.4067/S0250-71612002008500006.

PatagonLand. (2013). Reporte semanal unidad de inteligencia territorial: conurbación gran Temuco (Report No 19). Puerto Varas: Patagonland. Retrieved in 13 May 2015, from http:// www.patagonland.cl/wp-content/uploads/2013/07/ Research-19-PL-Conurbaciones-Gran-Temuco.pdf

Pino, E. (1998). Historia de Temuco. Temuco: Ediciones Universidad de La Frontera.

Reyes, S., \& Figueroa, I. (2010). Distribución, superficie y accesibilidad de las áreas verdes en Santiago de Chile. EURE - Revista Latinoamericana de Estudios Urbano Regionales, 36(109), 89-110. http://dx.doi.org/10.4067/ S0250-71612010000300004.

Rodríguez, J. \& González, D. (2006). Redistribución de la población y migración interna en Chile: continuidad y cambio según los últimos cuatro censos nacionales de población y vivienda. Revista de Geografía Norte Grande (35), 7-28.

Rodríguez, J. (2008). Movilidad cotidiana, desigualdad social y segregación residencial en cuatro metrópolis de América Latina. EURE - Revista Latinoamericana de Estudios Urbano Regionales, 34(103), 49-71.

Romero, H., Molina, M., Moscoso, C., Sarricolea, P., \& Smith, P.(2006) Caracterización de los cambios de usos y coberturas de suelos causados por la expansión urbana de Santiago, análisis estadístico de sus factores explicativos e inferencias ambientales. In: C. De Mattos, \& R. Hidalgo (Eds.), Reconfiguración Metropolitana y Movilidad Espacial en Santiago (p. 251-270). Santiago: Pontificia Universidad Católica de Chile.

Rovira, A. (2000). Puerto Montt: el paso de ciudad menor a centro de desarrollo interegional de una ciudad al sur de Chile. Espacio y Desarrollo 12, 84-101.

Ruíz-Tagle, J., \& López-Morales, E. (2014). El estudio de la segregación residencial en Santiago de Chile: revisión crítica de algunos problemas metodológicos y conceptuales.
EURE - Revista Latinoamericana de Estudios Urbano Regionales, 40(119), 25-48. http://dx.doi.org/10.4067/ S0250-71612014000100002.

Sabatini, F. (2000). Reforma de los mercados de suelo en Santiago, Chile: efectos sobre los precios de la tierra y la segregación residencial. EURE - Revista Latinoamericana de Estudios Urbano Regionales, 26(77), 49-80. http://dx.doi. org/10.4067/S0250-71612000007700003.

Sabatini, F., Cáceres, G., \& Cerda, J. (2001). Segregación residencial en las principales ciudades chilenas: Tendencias en las últimas décadas y posibles cursos de acción. EURE - Revista Latinoamericana de Estudios Urbano Regionales, 27(82), 21-42. http://dx.doi.org/10.4067/ S0250-71612001008200002.

Sabatini, F., Sarella, M., \& Vásquez, H. (2009). Gentrificación sin expulsión, o la ciudad latinoamericana en una encrucijada histórica. Revista 180, 24, 18-25.

Sabatini, F., Wormald, G., \& Sierralta, C. P P. (2007). Segregación residencial en Santiago: Tendencias 1992-2002 y efectos vinculados a su escala. Documento de Trabajo, 37, p. 1-33.

Saladié, Ò., \& Oliveras, J. (2010). Desenvolupament sostenible. Tarragona: URV.

Sanhueza, P., Díaz-Robles, L., Torreblanca, M., Schiappacasse, N., Silva, M., \& Astete, T. (2008). Particulate air pollution and health effects for cardiovascular and respiratory causes in Temuco City, Chile. Proceedings of the Air and Waste Management Association's Annual Conference and Exhibition, 59(12), 1481-1488.

Sanhueza, P., Vargas, C., \& Mellado, P. (2006). Impact of air pollution by fine particulate matter (PM10) on daily mortality in Temuco, Chile. Revista Medica de Chile, 134(6), 754-761. PMid:17130951.

Secretaría de Transporte - SECTRA. (2007). Indicadores tasa de motorización. Retrieved in 13 May 2015, from http://www.sectra.gob.cl/indicadores_de_movilidad/ Indicadores/tasa_motorizacion.html

Stadel, C. (2001). Ciudades medianas y aspectos de la sustentabilidad en la región andina. Espacio y Desarrollo, 12, 25-44.

Toledo, X., Romero, H. \& Garín, A. (2000). Segregación socioespacial de la comuna de Temuco. Espacio y Desarrollo, 12, 103-122. 
U.S. Geological Survey - USGS. (2011). Landsat Image. Retrieved in 1 May 2014, from http://landsat.usgs.gov/ Landsat_Search_and_Download.php

Universidad Diego Portales - UDP. (2012). Diagnóstico del transporte urbano en Chile. Análisis e indicadores para 28 ciudades chilenas. Santiago: Facultad de Ingeniería, Escuela de Ingeniería Civil Industrial.

Vergara, L. (2015). Globalización neoliberal y los cambios de una ciudad pequeña: El caso de Angol, Chile. Estudios Sociales (Santo Domingo, Dominican Republic), 23(46), 10-32.

Vergara, L., Gola, R. \& Huiliñir, V. (2015). Los inicios de la insustentabilidad: problemas urbanos e institucionalidad en la ciudad de Temuco, 1955-1970. Cuadernos de vivienda y urbanismo, 8(16), 264-281.

World Health Organization - WHO. (2010). Urban planning, environment and health: from evidence to policy action. Geneva: WHO. Retrieved in 13 May 2015, from http:// www.euro.who.int/_data/assets/pdf_file/0004/114448/ E93987.pdf

Wörner, B. (2001). Estudio de equipamiento y elementos de análisis urbano de la comuna de Temuco: oficina técnica plan regulador. Temuco: Municipalidad de Temuco, Secretaría de Planificación.

Received: May 13, 2015

Approved: December 07, 2015 